the methods of converting alternating current into high voltage direct current are still in the experimental stage, at least when dealing with power in bulk. Lord Kelvin was a great advocate for the transmission of electric power by direct current, and although most of the difficulties in working with alternating current have been overcome since his time, it is interesting to notice that several engineers still think that direct current will be used for trans. mission in the future.

\section{Data of Social and Economic Problems}

IN a recent number of Planning (16 Queen Anne's Gate, London, S.W.1) attention is directed to the lack of necessary data on many urgent social and economic problems. A civilisation has grown up under in. dustrialișm which calls for enormous resources of knowledge in order to operate it without constant and painful breakdowns. Yet we neither possess the required knowledge nor are we making at present any adequate effort to get it, although its provision offers no insuperable difficulties. Our whole attitude towards the question is still coloured by the prejudices and assumptions of a pre-scientific and pre-technical age. It has yet to be recognised that the same technique which has produced electricity, wireless, fertilisers and new breeds of plants and animals can, if suitably adapted, produce those social, political and economic inventions which we so desperately need.

WHILE the industrial executive in Great Britain and elsewhere has come to recognise that provision must continually be made for new patterns and new techniques, there is no corresponding awareness or equipment for checking and improving the performance of, say, the machinery of government, the health services or the handling of traffic. Immense problems such as the modern scourge of noise, of smoke and chemical pollution in air and water, of street accidents, of crime, of destruction of amenities and many others are allowed to grow up unchecked and almost unobserved. The problem is how to make effective the many demands for new knowledge which are at present frustrated because they do not promise profit to particular individuals or under. takings although they may involve great savings to the community. Obviously one solution would be a great expansion of State-aided research, but much more thought and inquiry would be needed before concluding that this is the only, or the best, solution.

\section{A New Arctic Island}

TrE discovery of a new island in the arctic is now a rare event, but in the Geographical Review of January, Mr. V. Stefansson describes what is probably such an occurrence. In September 1931 a party of Eskimo, searching for whales north of Alaska, came to an island on which they went ashore in a position of approximately lat. $71^{\circ} 20^{\prime} \mathrm{N}$., long. $145^{\circ}$ $30^{\prime} \mathrm{W}$. This is about 85 miles north of Flaxman Island and due east of Point Barrow. The island was reported to be about half a mile long and of the same width and to rise to an altitude of about fifty feet. There was some vegetation but no drift- wood. Mr. Stefansson vouches for the reliability of the Eskimo Takpuk who led the party and whose name has been given to the island. Further, he discounts the suggestion that the island was merely earth on floating ice. That part of the Beaufort Sea has been little explored though the nearest soundings, some twenty-five miles to the west, show deep water. The question arises as to the possibility of Takpuk Island being Keenan Land, reported in the 'seventies of last century and placed in various longitudes in about lat. $73^{\circ} \mathrm{N}$., but this seems more than doubtful. Photographs of Takpuk Island are reproduced with the article.

\section{The Australian Geographer}

The format has been remodelled and the scope changed of the Australian Geographer, the periodical published by the Geographical Society of New South Wales. It is hoped now to publish it more often than once a year and to give special consideration to the work of Australian writers on the geography of the continent. A special feature will be the continuance in every issue of a bibliography of Australian geographical literature. This feature, which begins with the year 1926 in the current issue (No. 1, vol. 2), should prove of considerable value. Another valuable article is that by Dr. M. Holmes in the Australian geographical environment, which treats the subject in much detail.

\section{Philosophy and Everyday Life}

THe organ of the Philosophical Society of England, the Philosopher, enters on its twelfth year of publi. cation under new editorship and in a new and attractive format. As is pointed out in the opening article, the special branches of science have found exponents capable of interpreting their many recent advances to the general reader, and it is the purpose of the Philosopher in a similar way to interpret current thought in philosophy and to indicate its contacts with the world of to-day. Thus in the issue before us there is an article on "Reason in Action" by Prof. John Macmurray, another on "Reflection and Common Sense" by Prof. A. E. Heath and another by Paul Painlevé, the distinguished French mathematician, philosopher and statesman who died towards the end of last year, on "Civilisation and Modern Science". Students of philosophy will perhaps turn more readily to the "Courses of Study", where notes are given on various aspects of the subject, with suggestions for further reading. There are also reviews and notices of recent books, a section on educational intelligence, a record of meetings of the Philosophical Society and so on. The journal has thus a double appeal, to the layman and to the student, and at the modest price of $6 d$. should have a wide circle of readers. Copies of the Philosopher can be obtained from the Honorary Secretary of the Philosophical Society, 13 Woodlands Road, London, S.W.13.

\section{Physica}

THE first number of the new Dutch periodical Physica (December 1933, pp. 96, published by Martinus Nijhoff, The Hague, 25 guilders yearly) 
contains a number of interesting papers. The paper by de Haas and his co-workers on the attainment of very low temperatures by adiabatic magnetic changes is referred to in our Research Items (p. 181). Druyvesteyn describes experiments on the lowvoltage arc in sodium vapour. The absorption of the $D$ lines was measured in the arc and the reversal of the $D$ lines against a continuous source at variable temperature was observed. The results show that the number of excited sodium atoms is about 12 per cent of the number of the normal atoms, and that the number of $\mathrm{Na}+$ ions is several times the number of normal atoms. The theory of light emission in gaseous discharges is discussed by W. De Groot. Van Heel describes a quartz-fluorite combination lens which is achromatic and spherically connected. It is intended for focusing light on a thermocouple with unit magnification. P. Cohen Henriquez describes a micro-apparatus for determining the dipole moment of organic solutes. The apparatus may be used with a few milligrams of material. The ratio of the lithium isotopes has been determined by intensity measurements of the fine structure of the $\mathrm{Li}$ resonance line by Ornstein, Vreeswijk and Wolfsohn. Van Kreveld describes an empirical summation law for a photographic plate exposed to light of two or more colours, and Van der Pol and Weyers describe the approximations known as Tchebycheff polynomials. The papers are in English or German, and in some cases German papers are provided with an abstract in English.

\section{Recent Acquisitions at the British Museum (Natural History)}

AMONG the recent acquisitions at the Natural History Museum the Department of Zoology has received as a donation from Mrs. Charles Buckley and $\mathrm{Mr}$. Godfrey R. Buckley the mounted head of a cow of the Chartley breed of cattle. Chartley Park was formed by enclosing about 1,000 acres of the forest of Needwood in the reign of Henry III, when a number of half-wild cattle, which then roamed throughout the district, were driven in and enclosed in the Park. Two important additions have recently been made to the beetle collections in the Department of Entomology, namely the Donisthorpe collection of British Coleoptera and an Australian collection purchased from Mr. W. du Boulay. The former contains upwards of 22,000 specimens, and is of especial interest in that it is accompanied by the most complete set in existence of the numerous British insects (mainly beetles) and other arthropods that live in association with ants and are known as myrmecophiles. The du Boulay collection, which numbers only 352 specimens, consists, however, entirely of beetles actually found inhabiting ants' nests in various parts of Australia by Mr. du Boulay over a period of sixteen years. Mr. R. E. Turner, working in South Africa, has collected and presented to the Museum some 8,000 insects of various kinds, principally small bees and wasps; and from the mountains of New Guinea Miss L. E. Cheesman has collected for the Museum upwards of 18,000 specimens. Miss M. Graves, M.P., has presented to the Geological
Department some portions of the egg-shell of a small horned dinosaur, Protoceratops andrewsi. The South Australian School of Mines and Industries has presented an end-slice of a large mass $(2,520 \mathrm{lb}$.) of meteoric iron found in 1909 at Murnpeowie, South Australia, previously represented in the collection only by a cast of the whole mass.

Sunday Lectures at the British Museum (Natural History)

For the benefit of visitors to the Natural History Museum on Sunday afternoons who may wish for fuller information about the various branches of natural history than may be obtained by casual wandering through the galleries, the Trustees of the British Museum have arranged for two lectures each afternoon at 3 and 4.30 , to be given usually by a member of the scientific staff. Lectures illustrated by lantern slides will be given in the Board Room, and the remainder in one of the galleries. The opening lecture will be on Sunday, February 4, the lecturer being Capt. Guy Dollman, who will speak on the great game animals of Africa and will show a number of lantern slides. On succeeding Sundays lectures will be given by Dr. W. E. Swinton on earthquakes, Mr. Maurice Burton on seashore animals (both in the Board Room), and Mr. J. R. Norman on the Fish Gallery. Admission to the lectures is free.

THE Department of Botany of the Natural History Museum has received a bequest of the herbarium of the late Ashley H. Maude. The specimens are well mounted on about 5,000 sheets and are in good condition, contained in four cabinets. They are chiefly European but there are also collections from Algeria, Cape Colony and the Canary Islands. The Godman Trustees have presented 534 specimens of flowering plants collected by $\mathrm{Mr}$. F. Ludlow and Capt. G. Sherriff in Bhutan. The area traversed is one which is not very well known botanically and as each 'number' comprises a good series of welldried plants the collection is of great value. A number of seeds were also collected, and these have been distributed. This year's collecting season in Nepal was ruined by the monsoon and consequently only fourteen specimens were collected by Prof. K. Sharma. These were presented to His Majesty the King and placed by him on loan in the Department of Botany. Although the number is small it includes several very important horticultural plants.

\section{Empire Museums and the Carnegie Corporation}

IT is gratifying to learn (from the December number of the Museums Journal) that the Carnegie Corporation has decided to grant substantial sums for the development of the museums of the Empire, following upon the Empire Survey of Museums, to which reference has been made in these notes. Already grants totalling 50,000 dollars have been made in Canada, and it has just been made known that similar sums have been set aside for South Africa, Australia and New Zealand. These will be administered by local committees. In addition to the 200,000 dollars thus earmarked, the Carnegie Corporation has also decided to appropriate 63,000 